Валентина ПАПУШИНА, orcid.org/0000-0003-4833-9049 кандидат філологічних наук, дочент, доиент кафедри украӥнської філології Хмельницького начіонального університету (Хмельницький, Україна) рарияһyna@ukr.net

\title{
КОНЦЕПТУАЛЬНІ ПІДХОДИ ДО ФОРМУВАННЯ ЕСТЕТИЧНОЇ КУЛЬТУРИ СТУДЕНТІВ У ПРОЦЕСІ НАВЧАННЯ ЛІТЕРАТУРИ
}

\begin{abstract}
Мета статті - представити кониептуальні підходи у межах запропонованої педагогічної системи формування естетичної культури студентів у прочесі навчання літератури, ще є підгрунтям для ії успішної реалізації. Виокремлено синергетичний, гносеологічний, аксіологічний, акметологічний, особистісно орієнтований, діяльнісний підходи. Практичне значення дослідження полягає у використанні запропонованих підходів для оптимізації процесу підготовки студентів філологічних спеціальностей. Взаємодія підходів до формування естетичної культури студентів створює фундаментальну методологічну основу практичного втілення сучасних вимог суспільства до фахового та естетичного рівня студентів.
\end{abstract}

Ключові слова: естетична культура, системний, синергетичний, гносеологічний, аксіологічний, акметологічний, діяльнісний підходи, особистісно-орієнтовані форми навчання, особистість, індивідуальність.

Valentyna PAPUSHINA,

Ph. D in Philological, Assistant Professor, Assistant Professor at the Chair for Ukrainian Philology, Khmelnytskyi National University (Khmelnytskyi, Ukraine) papushyna@ukr.net

\section{CONCEPTUAL APPROACHES TO THE FORMATION OF STUDENTS' AESTHETIC CULTURE IN PROCESS OF LITERATURE STUDYING}

Within the framework of proposed pedagogical system for the formation of students' aesthetic culture in the process of teaching literature to introduce conceptual general scientific approaches, which are the basis for its successful realisation. The article views the process of aesthetic culture formation during the study of fiction in higher educational institutions as a pedagogical system based on general scientific, conceptual principles. Conjunctive use of the features of the synergetic approach in formation of the student' aesthetic culture is considered within the very meaning of the concept of synergetics, on basis of it is the combination of general scientific approaches that enhance each other's actions, open attitude to new information, the synthesis of positive elements of each type of educational activity. Emphasize the epistemological approach as a process of understanding the interconnection of scientific knowledge and its methodology with the value-purpose orientation of the knowledge of beauty. Contribute to overcome the deficit of the aesthetic culture of the personality and create conditions for the development of students wish to its growth through the application of the axiological approach, which is based on the philosophical doctrine of moral, ethical, cultural values as the content-forming foundations of human existence. In the context of our study, we emphasize the basic values that reflect the attitude towards the beauty and the development of a correct judgment about it. With an acmetological approach, we associate the personality explosion, its highest achievements, the manifestation of high professionalism. Personally-oriented study of literature, we direct on creating conditions for a rigorous detection and development of the individual functions of a student's individuality through self-realization, self-development, self-education, self-regulation etc. Activity approach as a fundamental notion of pedagogical science is one of these conditions. Practical meaning of research is in using suggested conceptual approaches for optimization the process of philological students'studying. Interruption of the approaches to aesthetical culture formation makes fundamental methodological basis and opens possibilities for thinking and practical realization the modern demands of society to raise aesthetical level of graduate students. Prospects for further scientific research are seen in the extensive involvement to the aesthetic culture formation of students through different types of classical art and the scientific comprehension of perceiving forms.

Key words: aesthetic culture, systemic, synergetic, epistemological, axiological, acmetological, activity approaches, personally-oriented forms of study, personality, self-realization, self-development, self-education, self-regulation, individuality.

Постановка проблеми. Одним із важливих завдань сучасної освіти є формування всебічно розвиненої особистості, яка би вільно почувалась у будь-якому культурному середовищі, зберігаючи національні традиції і водночас відчуваючи причетність до європейської спільноти.
Розуміючи, що метою вищих освітніх закладів $€$ надання професійних знань, умінь та навиків, робимо наголос на необхідності засвоєння студентами загальнолюдських цінностей через формування естетичної культури, яка є складовою частиною професійної культури, толерантності, 
духовності, бачення кожним краси та гармонії світу.

Аналіз досліджень. Необхідність узгодження професійної підготовки із формуванням естетичних смаків та ідеалів молоді розглядають численні сучасні українські дослідники. Н. Волошина, Л. Джигун, М. Свтух, І. Зязюн, М. Киященко, Н. Миропольська, Т. Мороз, В. Халін, Г. Шевченко та інші дослідники провідне місце у підвищенні естетичної культури, крім інших видів мистецтва, надають художній літературі. Формування естетичної культури студентів у процесі навчання літератури у ВНЗ розглядаємо як педагогічну систему. Науково-методологічною основою іiї практичного втілення $є$ загальнонаукові підходи.

Мета статті - у межах запропонованої педагогічної системи формування естетичної культури студентів у процесі навчання літератури представити концептуальні підходи, що є підгрунтям для іiі успішної реалізації.

Виклад основного матеріалу. Одним із ключових шляхів пізнання та перетворення об'єктів дослідження $\epsilon$ системний підхід, який розглядається у багатьох сучасних наукових працях (В. Афанасьєв, I. Блауберг, С. Гончаренко, І. Зязюн, М. Каган, В. Кузьмін, І. Малафіїк В. Садовський, Г. Селевко, Б. Українцев, Е. Юдін та ін.) і виступає як сукупність елементів, що знаходяться у зв'язку й утворюють цілісність і єдність. Підтримуємо думку Г. Селевко, що системний підхід у педагогіці спрямовується на розкриття цілісності педагогічних об'єктів, виявлення в них різноманітних типів зв'язків і зведення їх в єдину теоретичну картину (Селевко, 2004: 141). Функціональні складові елементи системи загалом та окремі ії компоненти структуровані у певну внутрішню організацію і взаємодіють із нашою педагогічною системою. Процес систематизації навчальної та виховної діяльності відкриває широке поле для порівняння й узагальнення, пошуків оптимальних шляхів вирішення поставленої педагогічної проблеми.

У педагогіці системний підхід вимагає особливого ставлення до педагогічних об'єктів і «спрямований на розкриття їх цілісності, виявлення в них різноманітних типів зв'язку та зведення їх в єдину теоретичну картину» (Гончаренко, 1997: 72). Із позицій системного підходу, формування естетичної культури студентів у процесі навчання літератури, з одного боку, це складова частина формування особистості майбутнього спеціаліста, а з іншого - особистісно-діяльнісний підхід до суб' єкта виховання, спрямований на самовдосконалення кожного. Системний підхід визначає загальну мету та стратегію теоретичної і прак- тичної діяльності викладача, встановлює тісний взаємозв'язок з іншими суб'єктами професійнопедагогічної діяльності шляхом виявлення спільних цілей, розкриває внутрішні структурні компоненти, виявляє зв'язки із зовнішнім середовищем. Він спрямовує навчально-пізнавальний процес ВНЗ на розвиток особистості студента як активного учасника навчально-пізнавальної діяльності, спільний пошук вирішення професійних завдань, оптимізацію індивідуальних і групових форм взаємодії, поєднання зовнішнього контролю із самоконтролем і самооцінкою студентів. Це передбачає створення культурно-естетичного середовища, в якому студент може реалізуватись, самоутвердитись, самовизначитись як естетично довершена особистість.

На ідеях системності і цілісності світу, наукових уявлень людини про світ і саму себе в цьому світі базується синергетика - новий міждисциплінарний напрям науки, який вивчає закономірності й принципи, що лежать в основі процесів самоорганізації. Створюючи педагогічну систему формування естетичної культури студентів, ми виходили 3 наукових концепцій, що кожна система $є$ інтегративне утворення відкритого типу, що поєднує синергетичні риси: цілісність, організованість, цілеспрямованість, динамічність, керованість, самоорганізованість, гнучкість, мобільність, принциповість, інтенсивність, альтернативність. Комплексне використання рис синергетичного підходу у формуванні естетичної культури студентів виходить із самої сутності поняття «синергетика» (від грец. synergetikos - сумісний; той, що діє погоджено; спільна дія; sinergeia - співпраця, співдружність).

Висвітленню різних аспектів синергетичного підходу в гуманітарній площині за останні десятиліття присвячено численні наукові праці (В. Андрущенко, П. Анохін, В. Буданов, А. Добряков, О. Дубасенюк І. Зязюн, О. Князева, В. Кремень, В. Лутай та ін.). Погоджуємося 3 позицією I. Зязюна стосовно того, що синергетика створює уявлення про універсальну цілісність світу, дає змогу зрозуміти перехід хаосу в певну ієрархію, наочно ілюструє єдність у різноманітності й різноманітність в єдності, допомагає усвідомити нелінійність, багатофакторність і ймовірність реального світу, поліваріантність шляхів його розвитку й неможливість опису таких явищ на основі класичних теорій і моделей з їх лінійним уявленням про розвиток і самоорганізацію (Зязюн, 2008: 439). Педагогічна синергетика грунтується на законах і закономірностях самоорганізації і саморозвитку освітніх систем. Оскільки синергетичні риси грун- 
туються на науково-філософському принципі, що розглядає освіту й виховання як комплексну самоорганізовану систему, вона відкриває поле для новаторських спроб вирішення проблеми самовизначення і саморозвитку особистості через відкритість, співтворчість, що $є$ головним у нашій педагогічній системі.

При реалізації синергетичного підходу у формуванні естетичної культури студентів у процесі навчання літератури використовуємо комплекс загальнонаукових підходів, що в контексті нашого дослідження підсилюють дію один одного. У межах нашої педагогічної системи застосовуємо інноваційні педагогічні технології, визначаємо оптимальні психолого-педагогічні умови підготовки студентів. Синергетичний підхід дає змогу активізувати особистісні, інтелектуальні й творчі задатки студентів, виявити креативність на шляху самовдосконалення та самореалізації.

С. Гончаренко справедливо зазначає: «У педагогічному процесі явно проявляються взаємодії, які вивчаються синергетикою з її ключовим філософським положенням про відкритий характер будь-якої з соціальних систем - сучасною теорією спільної дії. Залежно від ступеня своєї відкритості системи взаємодіють між собою, причому у формі не лише боротьби протилежностей, яка раніше вважалася єдиним способом розвитку, а й співробітництва» (Гончаренко, 2008: 76). Синергетичний підхід узгоджується 3 міждисциплінарністью, розширюючи межі вивчення конкретного предмета шляхом залучення матеріалів дотичних дисциплін, даючи поштовх до інтеграції та компаративістики.

Серед концептуальних підходів, що виступають як методологічне підгрунтя запропонованої нами педагогічної системи формування естетичної культури студентів у процесі навчання літератури, виокремимо гносеологічний (від грец. gnosis, -seos - знання). У його основі лежить теорія пізнання (гносеологія), що вивчає природу, загальні передумови пізнання, можливості відношення знання до реальності, виявляє умови достовірності та істинності знань. Гносеологія розглядає процес пізнання з точки зору ставлення суб'єкта пізнання (дослідника) до об'єкта пізнання (досліджуваного об'єкта). Основна гносеологічна схема аналізу пізнання включає позицію суб'єкта, наділеного свідомістю і волею, і протиставленого йому об'єкта, незалежного від свідомості й волі суб'єкта й пов'язаного з ним тільки пізнавальними відносинами. Основне коло гносеологічної проблематики включає в себе інтерпретацію суб' єктом об'єкта пізнання (відповідно, сту- дента вищого педагогічного навчального закладу i навчального матеріалу, який підлягає засвоєнню), структуру самого пізнавального процесу, проблему істини і їі критерію (адекватність отриманого продукту пізнання реально існуючих еталонів), проблему форм і методів пізнання тощо.

Особливість гносеологічного підходу В. Петрушенко бачить у тому, що «основна увага приділяється процесу отримання знання через пізнавальні дії, окресленню критеріїв та способів перевірки його достовірності, вивченню структури та видів знання, особливостей його співвідношення 3 дійсністю, із засобами та способами пізнання, рівням та формам знань» (Петрушенко, 2005: 51). У цьому контексті естетичні знання розглядаємо як результат пізнавального процесу, як тотожне істині, науковому знанню як чуттєве пізнання прекрасного. При цьому враховуємо, що найбільш продуктивним гносеологічний підхід до набуття знань виявляється при дослідженні співвідношення змісту та форми знання (тобто того, як виражається знання).

У нашому дослідженні відштовхуємося від таких принципів гносеології: об'єктивність, пізнаваність, активне творче відображення, практика; оперуємо поняттями «пізнання», «свідомість», «відчуття», «краса», «розум», «істина». Виходимо з твердження, що виховання естетичної культури - це поєднання різнопланових знань, досягнення якого відбувається як самоорганізація і самодисципліна.

Унаслідок дефіциту естетичної культури особистості нині виникає потреба створення умов, які б сприяли розвитку прагнень студентів до росту естетичної культури. Із цією метою застосовуємо аксіологічний підхід (грец. aksios - коштовний), який грунтується на філософському вченні про моральні, етичні, культурні цінності як смислоутворювальні основи людського буття, що визначають напрями й умотивованість людського життя, діяльності, учинків у підготовці висококваліфікованого всебічно розвиненого спеціаліста.

На актуальності аксіологічного підходу, який іманентно властивий гуманістичній педагогіці, наголошували дослідники (Н. Асташова, Б. Гершунський, I. Ісаєв, А. Кирьякова, В. Крижко, Б. Лихачов, 3. Равкін, В. Сластьонін, Т. Садова, С. Шиянов та ін.). У працях вчених знаходимо такі визначення поняття «аксіологічний підхід»: філософсько-педагогічна стратегія, що визначає шляхи розвитку професійного мистецтва, використання педагогічних ресурсів для розвитку особистості і проектує перспективи вдосконалення системи освіти, основою якої $є$ принцип функціонального значення або цінності (Крижко, 
2005: 213); своєрідний «міст» між теорією та практикою, що, з одного боку, дає змогу вивчати різні явища і події з точки зору закладених у них можливостей щодо задоволення актуальних потреб людей, а 3 іншого - розв'язувати завдання подальшої гуманізації суспільства (Сластенин, Каширин, 2001: 162); орієнтація професійної освіти на формування в студентів системи загальнолюдських і професійних цінностей, що визначають їхнє ставлення до світу, своєї діяльності, самого себе як людини і професіонала (Садова, 2010: 63). Вбачаємо важливість розкриття аксіологічних принципів рівноправ'я всіх філософських поглядів у межах єдиної гуманістичної системи цінностей, необхідність вивчення і використання відкриттів минулого і сьогодення, їх передбачення в майбутньому. Аксіологію розглядаємо як нову філософію освіти та методологію сучасної педагогіки, в якій людина є вищою цінністю суспільства і самоціллю суспільного розвитку.

Аксіологічний підхід передбачає виховання позитивних настанов, ціннісних орієнтацій, морально-вольових якостей. Він дає змогу виокремити особистісні цінності, які розкривають сутність предметного світу та сприяють реалізації ціннісних пріоритетів у діяльності та стосунках, цілеспрямованому долученню до естетичної діяльності. У контексті нашої педагогічної системи вбачаємо основними цінності, які відображають ставлення до прекрасного та науковий рівень суджень про нього, особливого значення надаємо емоційному стану студента, що отримує радість від спілкування з прекрасним і від творення прекрасного ним самим. Студенти вчаться у своїй діяльності враховувати різні аспекти розуміння категорії «естетична цінність», відчувають необхідність задоволення естетичних потреб та інтересів, усвідомлювати естетичні цінності, що сприяють формуванню їх естетичної культури - це, зокрема, естетична свідомість, естетичний рівень художнього твору, естетичні ідеали, естетичні концепції, естетична оцінка.

У сучасній педагогічній науці відбулося становлення парадигми особистісно орієнтованої освіти, розробка іiі теоретичної моделі та впровадження досягнень науки в практику. Значний інтерес для нашого дослідження становлять засади особистісно орієнтованого підходу, розроблені у працях І. Беха, О. Бондаревської, М. Вікуліної, Р. Гришкової, О. Пєхоти, К. Платонова, А. Фасолі, I. Якиманської та ін. Так, О. Пєхота розглядає особистісно орієнтований підхід як важливий психолого-педагогічний принцип, основу якого становить сукупність вихідних теоретичних положень про особистість і практичних методичних засобів, які сприяють іiі цілісному вивченню та гармонійному розвитку (Пехота, 2000: 277).

У центрі уваги нашої педагогічної системи створення умов для повноцінного виявлення та розвитку особистісних функцій суб'єктів освіти. Для того щоб студент засвоював та перетворював на соціальний досвід знання, швидко адаптувався до умов життя, освіта та виховання мають закласти в ньому механізми накопичення знань та досвіду, збереження індивідуальності та життєздатності. Формування естетичної культури в процесі навчання літератури - основа для таких механізмів, оскільки будувати життя за законами краси - означає жити в гармонії зі світом і з собою. Надаємо пріоритет індивідуальності, самоцінності студентів, зосереджуємо увагу на індивідуальних потребах та можливостях самореалізації кожного, співпраці й співтворчості студентів, студентів і наставників, створенні ситуації вибору, актуалізації особистісного зростання як основи самостійності, стимулюємо розвиток й саморозвиток. Ми бачимо студента як співавтора всього освітнього процесу, відповідального за власні здобутки в царині естетичної діяльності. За мету нами поставлено знайти, підтримати, розвинути здібності й таланти в кожному через естетичну діяльність, виробити спільно зі студентом ним механізми його самореалізації, саморозвитку, самовиховання, саморегуляції.

Погоджуючись із думкою І. Якіманської, що в основі особистісного підходу «лежить визнання індивідуальності, самоцінності кожної людини, iii розвитку не як колективного об'єкту, але, передусім, як індивіда, наділеного своїм неповторним суб'єктивним досвідом» (Якиманская, 1996: 9), вважаємо кожного студента суб' єктом навчальновиховного процесу, який володіє певними власними здобутками естетичної культури, висуває індивідуальні потреби і має певні можливості їх задоволення.

Висновки. Отже, формування естетичної культури студентів у процесі навчання літератури у ВНЗ розглядаємо як педагогічну систему, що грунтується на загальнонаукових концептуальних підходах. Така взаємодія дає фундаментальну методологічну основу і відкриває простір для спрямування студентів на здобуття фахових професійних знань та відчуття потреби у підвищенні свого естетичного та культурного рівня. Перспективи подальших наукових розвідок вбачаємо в ширшому залученні до формування естетичної культури студентів різних видів класичного мистецтва та форм їх пізнання. 


\section{СПИСОК ВИКОРИСТАНИХ ДЖЕРЕЛ}

1. Гончаренко С. У. Український педагогічний словник. К.: Либідь, 1997. 374 с.

2. Гончаренко С. У. Педагогічні дослідження: методологічні поради молодим науковцям. К.; Вінниця: ДОВ «Вінниця», 2008. 278 с.

3. Зязюн І. А. Філософія педагогічної дії: монографія. Черкаси: Вид. від. ЧНУ імені Богдана Хмельницького, 2008. $608 \mathrm{c}$.

4. Крижко В. В. Антологія аксіологічної парадигми освіти. К.: Освіта України, 2005. 440 с.

5. Петрушенко В. Л. Філософія знання: онтологія, епістемологія, аксіологія: монографія. Львів: Ахілл, 2005.320 с.

6. Пєхота О. М. Особистісно орієнтована освіта і технології. Неперервна професійна освіта: проблеми, пошуки, перспективи. К.: Віпол. 2000. С. 274-297.

7. Садова Т. Аксіологічний підхід у системі педагогічної методології. Дошкільна освіта. 2010. № 1 (27). С. 63-69.

8. Селевко Г. К. Компетентности и их классификация. Народное образование. 2004. №4. С. $138-144$.

9. Сластенин В. А., Каширин В. П. Психология и педагогіка. М.: Академия, 2001. 480 с.

10. Якиманская И. С. Личностно-ориентированное обучение в современной школе. М.: Сентябрь, 1996. 96 с.

\section{REFERENCES}

1. Goncharenko S. U. Ukrai'ns'kyj pedagogichnyj slovnyk [Ukrainian pedagogical dictionary]. Kyiv: Lybid', 1997. 374 p. [in Ukrainian]

2. Goncharenko S. U. Pedagogichni doslidzhennja: metodologichni porady molodym naukovcjam [Pedagogical researches: methodological recommendations for young Scientifics]. Kyiv; Vinnitsya: DOV «Vinnycja», 2008.278 p. [in Ukrainian]

3. Zjazjun I. A. Filosofija pedagogichnoi' dii': monografija [Philosophy of pedagogical activity: monograph]. Cherkasy: Vyd. vid. ChNU imeni Bogdana Hmel'nyc'kogo, 2008. 608 p. [in Ukrainian]

4. Kryzhko V. V. Antologija aksiologichnoi' paradygmy osvity [Anthology of axiological paradigm of education]. Kyiv: Osvita Ukrai'ny, 2005. 440 p. [in Ukrainian]

5. Petrushenko V. L. Filosofija znannja: ontologija, epistemologija, aksiologija: monografija [Philosophy of knowledge: ontology, epistemology, axiology: monograph]. Lviv: Ahill, 2005. 320 p. [in Ukrainian]

6. Pjehota O. M. Osobystisno orijentovana osvita i tehnologii' [Self-oriented education and technologies]. Uninterrupted professional education: problems, searches, perspectives. Kyiv: Vipol. 2000. pp. 274-297. [in Ukrainian]

7. Sadova, 2010 - Sadova T. Aksiologichnyj pidhid u systemi pedagogichnoi' metodologii' [Axiology approach to the pedagogical methodology system]. Preschool education. 2010, Nr 1 (27). pp. 63-69. [in Ukrainian]

8. Selevko G. K. Kompetentnosti i ih klassifikacija [Competence and classifacation]. Public education. $2004, \mathrm{Nr} 4$. pp. 138-144. [in Russian]

9. Slastenin, Kashirin, 2001 - Slastenin V. A., Kashirin V. P. Psihologija i pedagogika [Psychology and pedagogic]. Moscow: Akademija, 2001. 480 p. [in Russian]

10. Jakimanskaja I.S. Lichnostno-orientirovannoe obuchenie v sovremennoj shkole [Self-oriented education in modern school]. Moscow: Sentjabr', 1996. 96 p. [in Russian]

Статтю подано до редакиії 16.05.2018 p. 